\title{
Creating duty on dominant firm: a case for alternative economic analysis
}

\author{
Prabhu Aloke Narasinga ${ }^{1}$ (D)
}

Received: 18 September 2019 / Accepted: 23 July 2020 / Published online: 21 August 2020

(C) The Author(s) 2020

\begin{abstract}
The desirability of creating norms within the framework of law has been a challenging process in a free market economy. The principles of antitrust law enunciated by courts in abuse of dominant cases has led to 'refusal to deal' as a contested doctrine. When dominance is treated as legitimate aspiration and free market choices are the medium to achieve the aspirations of free market enterprises, any duty or obligation cast on the firm is considered antithetical to the spirit of free market unless it eclipses the anticompetitive effect. Where an economic analysis of antitrust law has noneconomic impacts with ethical and moral issues, it calls for an alternative economic thought which also considers plural values of society. This also reflects a conflict arising out of lack of norms and respect for property rights. This paper attempts to analyze the cases and framework which is currently employed by the courts and the challenges it puts forth in creating a norm that is universal. The author by drawing on the principles of Gandhian economic thought and its essential features of trusteeship, non-possession and non-violence creates space for resolution of conflicts promoting ethical and moral considerations. Resolution of conflict through ethical and moral norms also assimilates the varied goals of antitrust regulation, including noneconomic goals when the goals of antitrust require a broader consideration that accommodates the wider spectrum of market participants.
\end{abstract}

Keywords Property · Norms · Gandhi · Free market · Antitrust · Refusal to Deal

Prabhu Aloke Narasinga is a Post-doctoral fellow at The Edmond J Safra Center for Ethics, Buchmann Faculty of Law, Tel Aviv University, Israel. This paper was presented in IIM Ahmadabad, as part of the third Law and Economics Conference held in September 2017. I am grateful for the comments and criticisms which has helped me to reform the paper in content and in form.

Prabhu Aloke Narasinga

aloke.prabhu@gmail.com

$1 \quad$ O.P Jindal Global University, Sonipat, India 


\section{Introduction}

In a free market economy, the principles of competition play a significant role in its governance and regulation. The evolution of free market though has been a contested one, but it has been largely believed that a free market system would bridge inequality and will foster economic growth. Likewise, neo-liberal values that came into vogue after the 1970s by the works of Friedrich Hayek and Milton Friedman helped unregulate and decentralise markets based on the free market principles. The Libertarians conceived freedom as economic freedom. A person is free if she is free to express her preferences in using and exchanging her private property without having to respond to the values and preferences of others. As such market and contracts are seen as allpurpose mechanisms for satisfying preferences (Hayek 1960; Friedman 1962; Nozick 1974). On the other hand, the critics of neo-liberal economic system contest that the socio-economic divide and inequality have widened and economics devoid of ethics has led to catastrophic results, specifically when an attempt is made on normative claims. The welfare economics that approach economic issues from an ethical dimension attempts to place the ethical considerations back as human-centric effort on market practice (Sen 1987; Nussbaum 2011). The conflict between and among the market participants and societal interests is stark within the developing economies that were decolonised in the twentieth century. The developing countries had to grapple with economic inequality, globalisation and neo-liberal forces and the global effect of trade further made the developing economies subject to the dominant developed economies as the economic regulations and policies had implications beyond borders (Fox 1997, 2011). This was also a result of globalisation and mindless adoption by the developing countries of the free market principles in the form of antitrust legislations (Sokol 2007).

The regulation of market in developing economies reflects stark contradictions that bring forth the concerns that are relevant for legal, economic, political and social institutions. Developing world or the Third World economies largely reflect markets that are socially embedded (Polanyi 2001), and these markets have yet to gain maturity as the developed Western economies. In USA and Europe, the evolution of antitrust principles was to an extent organic, whereas in the developing world, antitrust law was transplanted as a result of globalisation and hence the legal structure has yet to find balance between the socially embedded economic system and the free market principles.

In mature Western economies, courts have over a period of time created norms in an attempt to foster and sustain a competitive and conducive environment for market participants. The norms, though created by legal processes, were mindful of social norms, which determine how efficient an economy and its growth will be and its effect on the society. There was respect for contractual obligations and property rights, and the norms created trust adding to the economic growth (Landa 1995; Fukuyama 1996), whereas in developing economies, the norms are deeply embedded in a mix of economic and social values that were hierarchical and unequal. The vacuum of norms based on respect for contract and property rights along with the inorganic growth of free market principles has made it necessary for the developing countries to have their own prism and the freedom to evolve principles that are not derived from mature western economies. Any attempt to replicate the economic principles and analysis that is dominant in Europe and USA may not serve the developing countries. This paper 
hence argues that an ethical and moral anchor is essential for the developing countries when free market principles and traditional market come face to face, given the challenges the antitrust law itself faces in developed economies. The developing economies need to chart a way that requires a vibrant set of values that can be termed as pluralistic value based on liberal tradition with ethical concern for it to develop as an egalitarian society that does not sacrifice one for the other but balances the conflicts. The paper traces such conflict within the doctrine of refusal to deal where the courts have attempted to balance the freedom of the firm vis-a-vis the duty that it has specifically when the firm is dominant in the market.

\section{Assuming duty in refusal to deal cases}

This paper hence approaches the conflict within the market from the jurisprudence that has largely evolved and developed based on the doctrine of refusal to deal. Refusal to deal is not a per se illegal offense and therefore does not cast any unconditional duty on the dominant firm. These cases largely create vertical restraints and unilateral conduct and are generally assessed under rule of reason based on substantial market power threshold. It could lead to exclusion, barrier to trade and anticompetitive effect in the dominated or downstream market. On the other hand, any intervention that creates a duty on the dominant firm could be seen as dictating terms and forcing a contract that goes against the very principles of free market system. This also in a way deters economic activity and challenges economic freedom and growth. Antitrust law that provides rules of economic regulation also establishes a set of rules against private regulation (Nachbar 2013). Hence, any intervention that seeks to create a duty requires fine balancing and sound reasoning that would require its application in similar cases or cases that justify ascribing duty.

The property right regime that creates freedom of contract and trade envisages a minimal interference of law. When the firm refuses to deal or contract with competitors or firms in a free market system, what kind of obligations or duty mandates it to deal with the competitors has been largely decided by the courts based on the anticompetitive effect of such refusal rather than whether a duty exists, irrespective of the effect. After all, the free market system does not require that the firm thinks beyond its selfinterest and engage with the 'other'. It is only in conjunction with 'the other' and 'their rights' that the firm develops an obligation and a duty as it can be seen as correlative in a Hohfeldian sense. Where specific rights are absent, any attempt to create and cast a duty fails unless the economic activity in a wider sense encapsulates the interest of the society and other political and social commitments. Hence, the courts requires a wider context to create a duty based argument of to see anticompetitive effects. Other wise the court may fail to find rationale that can be replicated in similar circumstances. As every contract and every economic act in themselve, however insignificant, will have an anticompetitive effect, and so a mere existence of anticompetitive effect in itself would not justify its proscription.

So antitrust law that seeks to create duty based on effect of the conduct of dominant firm ventures into a slippery terrain as it tends to overlook ethical issues or has been seen as public interest issues. In the National Society of Professional Engineers 1978, case, it was argued that if engineers do not observe 'ethical' constraints on price 
competition, it would have adverse effect on the market as price competition could lead to reduced professional time applied to the engineering problem. Considering the public interest values though irrelevant to antitrust analysis that typically focuses on competitive effects, it is desirable to interpret such interests as part of any analysis though it may not be coextensive with the principles of competition.

In a free market economy, it is legitimate and largely acknowledged that in order for the firms to aspire to grow and economically flourish, it seeks to dominate, to widen its influence and to be monopolistic. The premise that dominance as an ideal is to be aspired itself appears to create harm and insecurity building barriers for trade unless viewed with an ethical anchor. The legitimising of dominance as an aspirational goal negates duty as it promotes self-interest devoid of public interest. Reflecting the legal philosophy of antitrust law, the court in Verizon Communication case has opined,

The mere possession of monopoly power, and the concomitant charging of monopoly prices, is not only not unlawful; it is an important element of the free-market system. The opportunity to charge monopoly prices - at least for a short period - is what attracts 'business acumen' in the first place; it induces risk taking that produces innovation and economic growth. To safeguard the incentive to innovate, the possession of monopoly power will not be found unlawful unless it is accompanied by an element of anticompetitive conduct.

What is legally desirable is to regulate the dominance of a firm, so that it does not create anti-competitive effect and manipulate the market. Whenever the courts have sought to regulate the dominant firm, the courts have created responsibility, obligation and probably a duty, as it affects the fairness and competitiveness of the market due to dominance. The courts have said that the dominant firm's actions should in no way hurt and unfairly affect smaller players, consumers or the larger societal interest in Compagnie Maritime Belge Transport SA v. Commission. The same court has also declared in Hoffman La Roche v. Commission 1979, that the very existence of dominance can raise a presumption of abusive effect on the market; this also reflects that dominance is not required to create anticompetitive effect. Some cases also do suggest that dominancy per se does not reflect anti-competitive effect. That is, in US v. Syufy 1990, the court has agreed that even if a firm has $100 \%$ market share, the firm may not be dominant, and in British Airways v. Commission 2003, a mere 39\% of market power indicates dominancy. The idealisation of dominance and the need to regulate dominant firm have generated friction of ideas and clash of philosophy that reflect both the theoretical premises of property rights and antitrust laws being questioned.

Any rule that seeks to cast duty in order to regulate the dominance has to be consistent and universal to an extent possible and this requires a far more logical and philosophical understanding of the market that goes beyond 'the firm and the market subjects'. A key point of the ethical economics is to see that it is rational to see business as a 'non-privative' as opposed to 'privative' activity where the rational principles of business management are cooperation, non-conflict and service, not exploitation. The cardinal principle is one of 'alteritas' considering the other and the need to consider and empathise the needs, interests and values, and it requires internalizing the alteritas that bring ethical values. One of the principles that are largely applied in cases that seeks to 
create duty on dominant firms were justifications that arouse out of necessity, that of 'essential facility' doctrine. It suggests that dominance is fine unless it does not threaten the very existence of other firms but the limitation of this rule being that it offers a narrow perspective. Its vantage point being that of the firm who is refused by the dominant firm to deal. What is overlooked in such cases are how does such refusal affect consumers and other firms in supply chain or markets where substitute products are not viable.

Adam Smith believed that the market manipulation is a natural tendency among market participants, and hence there is a need for regulation. Smith states, 'People of the same trade seldom meet together, even for merriment and diversion, but the conversation ends in a conspiracy against the public, or in some contrivance to raise prices' (Smith 1776). To conspire and dominate other market participants and be dominant is a tendency of free market enterprise. At the same time, Keynes in the opening paragraph of a 1924 lecture published in 1926 attempts to refute Adam Smith's doctrine of the invisible hand, and he says,

'The world is not so governed from above that private and social interest always coincide. It is not so managed here below that in practice they coincide. It is not a correct deduction from the principles of economics that enlightened self-interest always operates in the public interest. Nor is it true that self-interest generally is enlightened; more often individuals acting separately to promote their own ends are too ignorant or too weak to attain even these' (Keynes 1926).

Dominance in a neoclassical economy became an incentive for the market participants to engage in market process generating wealth through promotion of self-interest. Free market by nurturing this idea to extremes creates a legal conundrum and weakens social norms (Basu 2011). Antitrust law in its attempt to govern the market has proscribed abuse of dominance by taking an objective view of conduct in United Brands v. Commission 1978 and later in cases like Hilti AG v. Commission 1994. An objective view on each and every case could lead to fractured decisions, and it fails to create a universal principle that can be replicated. Universal principle-based judgements create patterns where the firm can behave knowing what is expected and an appropriate conduct can be reasonably presumed in a free market. As in a capitalist society, the weaker social norms have generated lesser respect for property rights creating more conflicts within the economy. It has forced the courts to interfere in the independence of firms by creating a form of duty of care and 'duty to deal'. The courts over a period of time recognised that by virtue of dominance a firm has the capacity to influence other players, choices of consumers and, ultimately, the power derived out of dominance can be used to maintain or leverage dominance to other sectors.

When the courts say that a firm has got a duty, a responsibility and an obligation, then, jurisprudentially, it indicates a counter right protected by law and enforced by the state indicating a property right. Property rights have enabled the emergence of free market world and to an extent it is considered a sacred one. It catapulted the industrialisation process and generated enormous wealth for the firm and its owners. A right which a firm has with respect to a patent is regarded as a temporary monopoly; property right with regard to a copy right is a right which can be waived; share is a distant property right, and a household right creates a permanent property right. Hence, 
to call an economic right as a property right signifies complex structure underlying the right. So, to see the property right as a bundle of right with end number of rights involved depending on the character of the property right makes such a right much contested and one of much consequence. The institution of property hence has undergone in the last two centuries a transformation of bewildering rapidity, and the failure of thought to keep pace with the needs causes no surprise.

The courts over a period have attempted to deal with the property rights in economic freedom in its own unique way by creating doctrines like 'refusal to deal' (Albertina 2006; Hovenkamp 2005). This principle is nothing but an attempt to understand the contours of property rights by attaching a function as conditionality to it. A function in terms of a duty underlying a right can only be justified and upheld if the 'function' is served. The function at times points towards the morality and ethics of property rights which lay dormant or ignored most of the times. Hence, any right devoid of function lacks obligations and such rights are perceived as it can do no wrong, as it stands on its own and it becomes a sovereign right (Tawney 1921). As there is no stated function to a right the narrative to create a duty let alone obligation is primarily routed through ethical and moral standpoint. The moral and ethical standpoint in a contract and property-driven free market has been weak and mostly ignored. This is also argued by many as a right-based system of free market as any non-right-based system fails to find its voice in a free market economy oriented towards contracts and property - the building blocks of free market system. This feature of right-based system is criticised and is identified as the reason behind the tendency of acquisitiveness in a capitalist society paving way to the conflicts and discontents in a society (Tawney 1921).

The same conflict and discontent can be traced through the cases of 'refusal to deal' where the rights devoid of function are challenged. Courts have found it difficult to rest its argument in favour of a duty to deal without going into the moral and ethical aspects of the contract and property. Dependence on the conventional theory of contract and property might end in sacrificing the non-economic goals of the antitrust law. The attempts therefore by the courts had been to infer or create duty in cases of refusal to deal when such refusal has no economic and legal justifications. Before venturing into the rights paradigm, we will attempt to understand significance and need for a noneconomic analysis-based approach to the antitrust law.

\section{Antitrust and non-economic goals}

The goals of antitrust law had been unsettled even after a century of jurisprudential arguments on it. When the capitalist economic philosophy itself is seen through a spectrum with divergent variants hardly finding a common ground, it is quite imaginable that this is reflected in the antitrust jurisprudence as well. The nature of regulation of an economy makes the goals of the antitrust law abstract (Bork 1967; Schwartz 1979; Möschel 1991). It has to take into account the nature of economy, the nature of regulation for such an economy and the specific instances where the application of antitrust jurisprudence is called for. In addition to the abstractness, the goals were primarily influenced by the economic philosophy and the various divergent determinants of the economy. The regulation was also influenced by social commitments of the state depending on whether the economy is mature, developed and geographically 
diverse, reflecting the market sentiments and economic philosophy specific to the time and space. Underlying all the determinants of regulations are norms, as all the commercial activities within a close group of traders and creation of contracts is influenced by normative values. Such norms reflect good faith that remains foundational for commercial transactions, acknowledged by law through the principle of 'Ubberimae fidae'(good faith) and 'Lex Mercatoria' (law of merchants). The underlying principles of good faith and law of merchants were nothing but norms created by trading society, which still plays an important role in the regulation of commercial transactions. Antitrust law appears to acknowledge norms in the form of good faith, fairness, competitiveness and societal interests. Likewise, the unwritten ethical and moral code of the society creates a healthy and sustainable environment and influences antitrust considerations.

Antitrust law creates a framework to harmonize the conflicts that arise out of economic transactions by fostering free market principles. Such firms that work in a free market environment have a dis-embedded view of the society. The case of refusal to deal is a classic example of such dis-embedded view where the firm fails to relate it with the society and its larger interests (Polanyi 1957). The legal framework and the courts over a period of time have attempted to consider broader objectives of the society (Möschel 1991). The difference of approach of jurisdictions and the objective of antitrust depending on the economy have led to diffusion of antitrust objectives. While the USA is more focused on the consumer welfare, in Europe the competition policy is focussed more on creating an economically efficient market (Bork 1978; Martin 2007; Zimmer 2012). Some consider competition law as a means to generate consumer welfare, who are advocates of 'utilitarian antitrust', which instrumentalises competition, claiming that competition without efficiency does not deserve protection. At the same time, Hovenkamp reflecting a popular sentiment points out eloquently that,

Judges have spoken of antitrust law as a "consumer welfare prescription" for so long that the phrase seldom produces anything but yawns... The rhetoric of consumer welfare is very powerful. A statute declaring protection of consumers to be the goal of antitrust would probably pass congress by a unanimous vote (Hovenkamp 2005).

Another point of view which emerged is that free competition is not an end in itself, it is but a means to an end. In its report on the mergers in contemplation on Safeway Plc and Asda Group Ltd, the UK Competition Commission observed that 'when working effectively, competition involves a process of rivalry between firms' (Furse 2008). This process constitutes a societal value in itself, even in the cases when this process does not lead to welfare gains, because vigorous competition between firms is the lifeblood of strong and effective markets. However, though the societal values in terms of ethics and morality have not found voice in the conventional antitrust jurisprudence, nevertheless, the challenges to the free market economy and an alternative to the narrow view based on efficiency and consumer welfare standards have brought in a much-needed broader perspective. In United States v. Von's Grocery Co 1966, the US Supreme Court in 1966 accommodated the small groceries in the Los Angeles area against the superior efficiency of the larger chains that threatened the consumers and the small market players like the individual groceries shop. As early as 1897 in the 
USA, the Supreme Court has expressed concern over combinations that reduced prices through efficiency in US v. Trans-Missouri Freight Ass'n 1897,. Judge Learned Hand later observed that social and moral considerations could properly override consumers' economic welfare as a primary determinant in US v. Aluminium Co of America 1945.

Many nations do not have a tradition of antitrust, especially Third World and developing as well as least developed economies and as such norms were not created by the courts unlike in USA or Europe. It was only in the latter part of the twentieth century that the nations in the developing world woke up to antitrust law and it was a result of globalisation rather than an as a natural process of maturing the domestic economy. In essence the free market and antitrust law was an import from the developed world. Many less developed and developing nations are concerned with the distribution of wealth, opportunity, access to markets and control over the power and perceived abuses of multinational enterprises (Fox 1996). Whether economic goals are the only concerns of antitrust regime is a question which one needs to consider especially in the context of developing and least developed economies (Bakhoum 2012). Concerns like the freedom of the firm to engage in a business or their right to hold and use the intellectual property eclipse the ultimate purpose of welfare. Competition law just does not seek a free market economy, but in doing so, it wants to achieve a better standard of life to the people and more importantly it tries to achieve an ulterior objective of fairness, equality and well-being of the people in a society where the weakest person will have the opportunity and freedom to excel through his hard work. But many a times, this objective was overlooked in pursuing pure economic goals. The difference in opinion as to the objectives of the competition law has led to conflict of opinions as what constitutes the ultimate goal of the antitrust law as it has a significant bearing on the emergence of 'refusal to deal' as a principle that looks for a duty as a critique to the free market philosophy.

\section{Balancing the conflict of rights and duties}

One of the most enduring and influential work on the matrix of rights has been done by Wesley Newcomb Hohfeld where he elaborated on the relational approach of rights and duties (Hohfeld 1913, 1917). He was concerned with the loose right talk that still infests the economics literature today. Rights as is generally been termed and used might most of the time belong to a spectrum that can be pointed by privilege, power and immunity rather than a right in the strict sense of the word. To understand this matrix, he created the jural relations, where rights and duties were jural correlatives and to establish a right one need to identify a correlative duty. So, to claim a freedom, liberty or even privilege, a firm as a market participant need not necessarily to argue anyone or even everyone has some duty, as others too may possess the same attributes. A right is not vested in a person because he merely asserted it, a claim of a right amounts to nothing more than a prediction that a court will enforce the interest of the claimant in the face of some challenge. Hence, a claim that does not point out a right also could create duty and any conflict that gives rise to an argument of duty needs to establish a better claim.

The conflict of interest in a free market economy stems from two distinct kinds of conflicts: one which is inherently a conflict between public and private interests and the other which indicates a conflict between private interests. 'Refusal to deal' indicates a 
tussle between the private interests but nonetheless has public interest ramifications. As refusal to deal is not per se illegal in any jurisdictions, there is no unconditional duty to deal as pointed out in Verizon Communications v. Law Offices of Curtis V Trinko LLP 2004. [I]n US v. Colgate 1919, the court has observed that in the absence of any purpose to create or maintain a monopoly, the [Sherman] act does not restrict the long recognized right of trader or manufacturer engaged in an entirely private business, freely to exercise his own independent discretion as to parties with whom he will deal. Any intervention by the courts also require it to act as central planners, identifying the proper price, quantity and other terms of dealing, a task to which they were ill-suited as was observed in Verizon Communications v. Law Offices of Curtis V Trinko LLP 2004.

The courts have also found that enforcement of any duty to deal may be difficult as the terms and conditions of such duty requires the court to undertake a venture that it is ill-suited to do in terms of understanding the functioning of the market and its practice. If the courts shy away from interventions purely based on legal considerations, and if primacy is given to the individuals' legal right, then the interests of the larger public and their welfare would have to be sacrificed, and in the long run individuals could become more vulnerable as he will be only driven by self-interest. If the individual interest is to be better served, public interest has to be protected as the individual is a part of the society and his existence is dependent on the larger society and its interest.

Likewise, in India, the courts while deciding Re All India Organisation of Chemists \& Druggists and Others 1996, have acknowledged that the boycott of a particular drug manufacturer will hamper the availability of essential drug in the market especially when the firm was a producer of essential drug and it is not in the larger interest of the society. When social harm is evident, such conduct cannot be approved though the court in the case did not consider anticompetitive effect of the conduct from a purely antitrust analytical framework. It suggests that right to property should not be construed in such a manner which negates the public interest and the societal development. It's not just the narrow economic concerns, but competition law can serve a democratic purpose, in the process ensuring the observance of the rule of law (Vedder 2009).

This indicates that even in a free market economy there is a need to create an obligation on the dominant firm. Courts though developed essential facility doctrine to justify its creation of duty and obligation to deal but it could only be applied in cases where the sharing is essential for the competitor to enter/exist in the market. The attempts of court to find an amicable solution by reading obligations on dominant firms has met with limited success. If the law does not create obligations, a dominant firm may utilize its monopoly power in an unjustifiable manner. Creation of obligations on dominant firm to deal with other firms and circumstances for the courts to interfere is a matter of great contest and is objectively justified and by context in Benzine en Petroleum Handelsmaatchippij BV v. EC Commission (1978)). When we say a firm has a 'duty', the burden of proof falls on the dominant firm and creates a presumption that to establish its right not to deal is with the dominant firm. Being a dominant firm and being in an advantageous position, it would be more fair to ask the dominant firm to show the burden of proof rather than the plaintiff, and the dominant player should be required to show that by forcing it to deal would amount to a violation of its rights as a free market player or its trade rights. 
The duty of a dominant player has been explained by courts in various cases directly and even indirectly without a reference to the duty as such. The European Court of Justice has held that a dominant firm has a special responsibility towards the competitive process 'not to allow its conduct to impair genuine undistorted competition on the common market' in Michelin v. Commission 1983, and again in Tetra Pak II 1996; P Compagnie Maritime Belge Transports SA v. Commission 2000, the courts have observed that the responsibility grows with the degree of dominance.

The dominant firm as an owner cum user of the facility along with other users can be cast with a duty to separate its management as an owner from being a user of the facility so that other users will be treated equally and at par with the owner as he should only be considered as a user of the facility rather than the owner of it. Hence, there should not be leveraging or exercise of dominance that should be allowed. In Sea Containers/Stena Sealink 1993, the existence of dominant power was eliminated by the court, though the dominant firm sought to exercise the dominance being the owner of the facility. This decision indicates a liberal interpretation of property rights. The domain of ownership is restricted indicating that ownership rights cannot be used to leverage one's right into the domain where others interest are harmed. In United Brands v. Commission 1978, a case of refusal to sell, the court cast a positive duty on the dominant firm by making it obligatory to sell to a long-standing customer unless there are objective reasons to justify not to do so. This decision takes one beyond the framework of law into an area of obligation, again reflecting a liberal interpretation of property rights that proscribes a conduct as harmful to the larger market participants though cannot be strictly called as unlawful. Going a step ahead, Advocate General Jacobs opined in Oscar Bronner $\mathrm{GmbH}$ and Co. KG v. Mediaprint Zeitungs- und Zeitschriftenverlag GmbH and Co. KG and Others 1998, that a dominant undertaking must actively promote competition by allowing potential competitors access to the facilities which it has developed.

It is largely believed that any obligation to deal may discourage innovation both by the dominant firm and its competitor which indicates a tension between static and dynamic efficiencies. The static efficiency by way of a lower price may indicate consumer welfare and dynamic efficiencies may be created through innovation and creation of new products, but these are indicators. The acceptance of market power for long has been a way to promote investment and innovation incentives and dynamic efficiency. This tension between forced sharing and incentives to invest has been noted both by the Supreme Court of US in Verizon Communications v. Law Offices of Curtis $V$ Trinko, and in Oscar Bronner v. Mediaprint Zeitungs - und Zeitshcriftenverlag Gmb $H \& C o . K G$. This tension between forced sharing and incentives is especially acute in the sphere of intellectual property, where the intellectual property right is specifically granted to investors as a reward for effort. But at the same time, this leads us to a bigger problem that in such cases enforcement may be difficult and costly and the Competition Authority or court may have to consider what terms of dealing it is reasonable to impose, a task the courts are not capable to perform most of the times.

In the UK, the Competition Appeal Tribunal (CAT) in Genzyme Limited v. OFT 2004 held that a firm that had abused its dominant position through the operation of an unlawful margin squeeze was primarily responsible for bringing the abuse to an end and that a direction should be necessary only if it was unwilling or unable to find a solution. The judgement thus initially gave the parties a period to negotiate a remedy. Since, however, the conduct of the dominant firm essentially precluded a negotiated 
settlement, the CAT in the end, imposed directions erring in favour of an approach which would be more likely to stimulate than mute competition.

Mostly, the courts have discreetly held in cases cutting across different jurisdictions that in a free market economy, market participants are not guided by just economic efficiency, but being part of social cosmos, their responsibilities and obligations cannot be ignored when they are benefited from the protection of property rights under the legal structure. Gregory Alexander hence stresses on the point that individual autonomy is only possible in the context of the dependence upon communities of other persons who facilitate the development of the capabilities which together are necessary for autonomy as self-governance (Alexander 2018). A free market economy and the firms in a free market economy in order to claim self- regulation and autonomy have to realise the commitment and relation in which they are embedded with the society.

\section{Antitrust and trusteeship}

To harmonise the conflict of interest and to create limitations on property rights, this paper would suggest an alternative thought process that is primarily moored in the ethical and moral foundations of market. This approach takes a moral-centric view of economic activity and seeks to create norms that are morally rooted. This also blurs the point where private and public law gets differentiated. One can also see a bipolar view based on the two premises: At one hand, there is an agreement that the market norms do a better job of embodying ways we properly value a particular good than norms of other spheres; and on the other hand we may also believe that the market norms do not as such undermine important ideals such as freedom, autonomy and equality, or important interests legitimately protected by the state. So, these premises do not in any way dis-embeds the society value vis-a-vis the economic values but the attempt is to balance the value norms of the modern market in embodying an economic conception of freedom. Such norms were in existence and economists, and thinkers like Karl Polanyi, E. F. Schumacher, R Tawney and E P Thomson have argued for different variants and elaborated on it from time to time.

Similarly, Gandhi invokes an economic philosophy that is based on economic equality that is brought forth by a system of trusteeship. For Gandhi economic activity should ideally indicate moral progress as he says, 'By economic progress we mean material advancement without limit, and by real progress we mean moral progress... I hold that economic progress in the sense I have put it is antagonistic to real progress' (Gandhi 1922, 34; Kumarappa 1945). This can also be seen as a bottom-up approach as norms are created by market participants that are based on autonomy and equal opportunity. Gandhi's alternative approach are qualitative and spiritual approaches to development as Amartya Sen puts it - that it enables deprived people to take part in the process of social development in order to restore their capability (Dreze and Sen 1989). Hence, access to market is part of a democratic process where the goods in a market economy can be secured through a form of democratic provision that is nonexclusive, principle and need regarding, and regulated primarily through voice. Hence, dominance based on self-interest fails in as much as it fails to protect the plural sentiments of the society, especially its weaker participants. 
The Gandhian approach becomes pertinent where the private affluence and public poverty of the free market economy and the neo-liberal economic policies have created a divide that can only be bridged by a perspective which has to be inclusive. A balancing of the individual and the public interests and the firm's obligations and responsibilities vis-a-vis its freedom of trade and contract is a necessity; and eclipsing one for the sake of the other can be catastrophic. Hence, Gandhi calls for the capitalists to use his property or dominance as a capacity to be seen from the vantage point of a trustee for the ultimate benefit of the beneficiaries that is in consideration of the public interest. It is based on the faith that human nature is never beyond redemption, and hence trusteeship as a principle recognizes the right to private property in the means of production as long as it is subservient to the community interests (Gandhi 1968). This approach helps to create a universal principle that is legally sound, and it also helps create norms that are deeply rooted in the society. The legal obligations of a trustee are similar to that of a firm that exercises the freedom with realisation that its existence is dependent on the obligations towards the society.

Trusteeship hence provides the necessary framework to create norms for the market participants and obligations are understood as part of the firm's existence rather than a forceful, violent and coercive method that is alien to the free market principles. Any such perspective of property as trusteeship does not just reduce the friction between competing interests but it develops a much-required vantage point to think from the perspective of the weakest player in the economy. This perspective also tends to cultivate pluralistic values where the firms consider more than their self-interest promoting inclusive approach in its market transactions. This also takes care of the larger purpose of law to create a narrative for the economic players to engage in an economic transaction with a sound basis of morality and ethics. In Genzyme Limited v. OFT 2004, the court indicated that an obligation if understood by the parties and willing to modify their conduct would be most appropriate where a legal intervention is not desirable. These cases have indicated that a legal solution to all market problems is not possible, but what is required is a sense of cooperation towards other participants rather than a 'right'-based approach. The problem with rights evolving out of the contracts are that a counter duty is towards the party involved in the contract and not towards the society even if there is negative externality involved. Hence, what the economic man tragically lacks is a sense of 'commitment' a trusteeship-based approach, a sense which is unlike sympathy or benevolence, that requires ethical and moral considerations. It also contributes to non-violence as a co-operative tendency matures into a healthy economic transaction rather than by a force of law.

The free market-based principles were also a victim of a trend that ignored the in rem rights of the property and focused more on in personam rights in line with the 'bundle of rights theory' (Merrill and Smith 2001). The in rem character of property and its consequences are vital to an understanding of property as a legal and economic institution. Thomas W. Merrill and Henry E. Smith in their essay 'What Happened to Property in Law and Economics' argues that the decline of the conception of property as a distinctive in rem right in Anglo-American thought, is connected with the rise of the view of modern legal economists that property is simply a list of use rights in particular resources. This also in some way supports the approach that Gandhi takes on property when he signifies the in rem character of the property right should also be mindful of the interests and welfare of the society (Gandhi 1942). As Blackstone, Smith 
and Bentham recognized, the tried-and-true method of handling potential conflicts over resources among large numbers of claimants is to create in rem property rights - rights that give one person the ability to exclude all other claimants to the resource and thereby determine its use. Gandhi seems to go a step further and say that it's not just the in rem rights but the utility of the wealth to the society which should determine the property right, because if the wealth is in no way benefiting the larger society then such wealth and its protection is meaningless. Any economic policy which supports property rights in derogation of the duties which is attached to the property rights will always be contested as it is inherently in conflict with the context the property rights are justified. So it's conducive to see the property rights in terms of trusteeship if one considers property rights in cases like refusal to deal that needs an ethical framework.

\section{Conclusion}

In a free market economy, fast moving towards a greater value assigned to intangible property the contestations on the contours of property has also similarly increased. Whether knowledge, data or intellectual property as the source of property, complex nature of conflict between different constituents has gained momentum as intangible property rights have become a source of friction adding to the complexity of property rights.

The increase in contests and conflicts on contracts and property and the inability of courts to create a duty or to see a functional justification of rights have necessitated a revisit of the philosophical grounds that gives legal protection to firms in their quest for dominance and economic power. It suggests that we need to go beyond an economic analysis of property rights and in a free market economy where the contours of property are ever widening and undetermined the larger perspective that is inclusive is to be considered. As such the Gandhian economic philosophy and his adaptation of trusteeship as an ideal could help widen the scope for interpretation and the criteria for determining a case of 'refusal to deal'. It also reflects on the difficulties for the court to see as to what are the limitations of the property rights and what are the duties and obligations attached to the rights which can be ascertained and understood as property rights. Gandhi's model of trusteeship is an attempt to create norms without force of law, and in some sense it can be seen as a political theory rather than a legal theory having its foundations in making non-violent, voluntary action and fostering plural values in a society that is moving on the lines of free market economy with growing inequality and hence growing discontents. Hence, the inclusiveness of trusteeship as a theory is not just an attempt eliminate conflict but also an attempt in creating norms having its foundations in the rule of law, assimilating the different constituents of society. Hence, Gandhi affirms, 'Earn your crores by all means. But understand that your wealth is not yours; it belongs to the people' (Gandhi 1942). This indicates that there is virtue in creating wealth but more than that any creation of wealth should be in sync with the needs of the community. Creation of wealth is only meaningful when such wealth flows into the society enriching it and bringing prosperity.

Legally, any right has to find its right balance in creating obligations and duties which could justify such right morally and ethically for it avoids discontent and create 
sustainability. This has become inevitable in this time of great ferment when the economic growth has led to islands of prosperity in the desert of poverty with values that justify accumulation of wealth and dominance by the capable over the weak. Hence, any economic progress requires a moral anchor for it to be meaningful apart from creating plural values that enables the wider spectrum of market participants.

Open Access This article is licensed under a Creative Commons Attribution 4.0 International License, which permits use, sharing, adaptation, distribution and reproduction in any medium or format, as long as you give appropriate credit to the original author(s) and the source, provide a link to the Creative Commons licence, and indicate if changes were made. The images or other third party material in this article are included in the article's Creative Commons licence, unless indicated otherwise in a credit line to the material. If material is not included in the article's Creative Commons licence and your intended use is not permitted by statutory regulation or exceeds the permitted use, you will need to obtain permission directly from the copyright holder. To view a copy of this licence, visit http://creativecommons.org/licenses/by/4.0/.

\section{References}

Albertina, A.-L. (2006). Refusal to Deal and Objective Justification in EC Competition law. The Cambridge Law Journal, 65(1), 24-27.

Alexander, G. (2018). Property Law and Human Flourishing. New York: Oxford University Press.

Bakhoum, M. (2012). Reflection on the concepts of 'economic freedom', 'free competition' and 'efficiency' from the perspectives of developing countries in the goals of competition law ed by Daniel Zimmer, UK: Edward Elgar.

Basu, K. (2011). Beyond invisible hand: groundwork for a new economics (pp. 33-41). New Delhi: Penguin Books.

Benzine en Petroleum Handelsmaatchippij BV v. EC Commission. (1978). C-77/77 ECR 1513.

Bork, R. H. (1967). The goals of antitrust policy. The American Economic Review. Vol. 57, No. 2, Papers and Proceedings of the Seventy-ninth Annual Meeting of the American Economic Association, 242-253.

Bork, R. H. (1978). The antitrust paradox: a policy at war with itself. New York: Simon and Schuster.

British Airways v. Commission. (2003). T-219/99.

Dreze, J., \& Sen, A. K. (1989). Hunger and public action. Oxford: Oxford University Press.

Fox, E. M. (1996). Trade, Competition and Intellectual Property - TRIPS and its Antitrust Counterparts, Vand. J. Transnat'l L. 29. 481.

Fox, E. M. (1997). Toward world antitrust and market access. The American Journal of International Law, 91(1), 1-25.

Fox, E. M. (2011). Antitrust without borders: from roots to codes to networks. In A. T. Guzman (Ed.), Cooperation, comity, and competition policy (pp. 265-280). New York: Oxford University Press.

Friedman, M. (1962). Capitalism and Freedom. Chicago: Chicago University Press.

Fukuyama, F. (1996). Trust: the social virtues and creation of prosperity. New York: Free Press.

Furse, M. (2008). Competition law of the EC and UK (6th ed.). Oxford: Oxford University Press.

Gandhi, M. K. (1922). Hind Swaraj or Indian home rule (5th ed.). Madras: Ganesh \& Co.

Gandhi, M. K. (1942). February. Harijan, 20.

Gandhi, M.K. (1968). in S. Narayanan (ed.) The Selected Works of Mahatma Gandhi. Six Volumes, Ahmedabad: Navajivan Trust, VI 368.

Genzyme Limited v. OFT. (2004). C-1016/1/03, CAT 4.

Hayek, F. (1960). The Constitution of Liberty. Chicago: Chicago University Press.

Hilti AG v. Commission. (1994). C- 53/92P, ECR I-666.

Hoffmann-La Roche v. Commission. (1979). C-85/76.

Hohfeld, W. N. (1913). Some fundamental legal conceptions as applied in judicial reasoning. Yale Law Journal, 23, 16-59.

Hohfeld, W. N. (1917). Fundamental legal conceptions as applied in judicial reasoning. Yale Law Journal, 26, $710-770$.

Hovenkamp, H. (2005). The antitrust enterprise: principle and execution (pp. 291-300). Cambridge: Harvard University Press. 
Keynes, J. M. (1926) (1963). "The end of laissez-faire" in essays in persuasion, New York: W. W. Norton, $1963,312$.

Kumarappa, J. C. (1945). The economy of permanence. Varanasi: Sarva Seva Sangh Prakashan.

Landa, J. T. (1995). Trust, ethnicity and identity: beyond the new institutional economics of ethnic trading networks, contract law, and gift exchange. Ann Arbor: University of Michigan Press.

Martin, S. (2007). The goals of antitrust and competition policy, Purdue CIBER working paper -003. https://docs.lib.purdue.edu/ciberwp/48/. Accessed on 09/03/2020.

Merrill, T. M., \& Smith, H. E. (2001). What happened to property in law and economics? Yale Law Journal, $111,357$.

Michelin v. Commission. (1983). 322/81, ECR 3461, para. 57.

Möschel, W. (1991). The Goals of Antitrust Revisited, Journal of Institutional and Theoretical Economics (JITE) / Zeitschrift für die gesamte Staatswissenschaft. The New Institutional Economics New Views on Antitrust, 147, 7-23.

Nachbar, T. B. (2013). The Antitrust Constitution, 99 IOWA L. Rev. 69.

Nozick, R. (1974). Anarchy, State, and Utopia. New York: Basic Books.

Nussbaum, M. (2011). Creating Capabilities. Cambridge MA: Harvard University Press.

Oscar Bronner GmbH \& Co. KG v. Mediaprint Zeitungs- und Zeitschriftenverlag GmbH \& Co. KG and Others. (1998). C-7/97 ECR I-779, para. 34.

P Compagnie Maritime Belge Transports SA v. Commission. (2000). C-395-296/96, ECR I-1364, opinion of Fennelly AG, para. 1137, para 112-19 (ECJ).

Polanyi, K. (1957). The great transformation. Boston: Beacon Press.

Polanyi, K. (2001). The Great Transformation: The Political and Economic Origin of Our Time. 2nd ed. Forwarded by Joseph E. Stiglitz. Boston: Beacon Press.

Re: All India Organization of Chemists and Druggists and Ors. (1996). 21 CLA 322.

Schwartz, L. B. (1979). "Justice" and other non-economic goals of antitrust. University of Pennsylvania Law Review, 127(4), 1076-1081.

Sea Containers/Stena Sealink. (1993). OJ 1994 L15/8, para. 66.

Sen, A. (1987). On Ethics and Economics. New York: Basil Blackwell.

Smith, A. (1776) (1937). An enquiry into the nature and causes of wealth of nations. Repr., New York: Random House.

Sokol, D. (2007). Monopolists without borders: the institutional challenge of international antitrust in a Global Gilded Age, 4 BERKELEY BUS L.J. 37.

Tawney, R. H. (1921). The acquisitive society. London: G Bell \& Sons.

Tetra Pak II. (1996). C-333/94P, ECR I-5951, para. 24.

United Brands v. Commission. (1978). C-27/76, ECR 207.

United States v. Aluminium Co of America. (1945). 148 F. 2d 416, 429 (2nd Cir. 1945).

United States v. Colgate. (1919). 250 U.S. 300, 307.

United States v. Trans-Missouri Freight Ass'n, 166 U.S. 290, 323. (1897).

United States v. Von's Gorcery Co., 384 U.S. 270. (1966).

US v. National Society of Professional Engineers, 435 U.S. 679. (1978.

US v. Syufy. (1990). 903 F.2d 659 9th Cir.

Vedder, H. (2009). Of jurisdiction and justification. Why Competition is Good for Non-Economic Goals, But May Need to be Restricted, Competition Law Review, 6, 51-75.

Verizon Communications v. Law Offices of Curtis V Trinko LLP. (2004). 540 US 398.

Zimmer, D. (2012). The basic goal of competition law: to protect the opposite side of the market in the goals of competition law ed by Daniel Zimmer, UK: Edward Elgar.

Publisher's note Springer Nature remains neutral with regard to jurisdictional claims in published maps and institutional affiliations. 